\title{
BACTERIAL PROFILE AND DRUG SUSCEPTIBILITY PATTERN OF URINARY TRACT INFECTION IN INFANTS AND CHILDREN
}

\author{
Jyothiprakashraju Sampathirao1, Radhika Budumuru², Bala Chandrasekhar Pappala ${ }^{3}$ \\ ${ }^{1}$ Assistant Professor, Department of Paediatrics, Great Eastern Medical School and Hospital, Srikakulam. \\ ${ }^{2}$ Assistant Professor, Department of Microbiology, Great Eastern Medical School and Hospital, Srikakulam. \\ ${ }^{3}$ Assistant Professor, Department of Microbiology, Great Eastern Medical School and Hospital, Srikakulam.
}

\begin{tabular}{l}
\hline ABSTRACT \\
\hline BACKGROUND \\
The biggest concern over UTIs in children is that they can cause permanent kidney damage and scarring. Repeated scarring can \\
lead to high blood pressure and reduced kidney function including kidney failure. Infants and young children seem to be at higher \\
risk for this complication.
\end{tabular}

\section{OBJECTIVES}

The aim of this cross-sectional study was to identify bacterial agents and their antibiotic susceptibility pattern isolated from infants and children with UTI attending Paediatric OP in GEMS Medical College, Srikakulam.

\section{METHODS}

Nineteen infants (Below 1 yr.) with excessive cry and strain on micturition and eighty one children (Below 12 yrs.) with burning micturition $(n=100)$ were investigated for urinary tract infection from January to March 2015 by standard microbiological techniques.

\section{RESULTS}

Infants and children were included in this study. Bacteriological screening of mid-stream urine specimens revealed that $66 / 100(66 \%)$ had significant bacteriuria in these groups. The bacterial pathogens isolated were predominantly E. coil (46.9\%) followed by K. pneumoniae (25.7\%), coagulase-negative staphylococci (10.6\%). Others found in small in number included pseudomonas aeruginosa (6.06\%), P. mirabilis (4.54\%), Enterococcus spp. (4.54\%) and non-Group A beta-haemolytic Streptococcus (1.54\%). The gram positive and negative bacteria accounted $16.66 \%$ and $83.34 \%$ respectively. The susceptibility pattern for gram-negative bacteria showed $100 \%$ sensitive to meropenem, $96.2 \%$ to nitrofurantoin, $94.4 \%$ to amikacin, $87.01 \%$ to ampicillin plus tazobactam, $81.4 \%$ to gentamycin, $79 \%$ to ofloxacin, $72.2 \%$ to cotrimoxazole, $55.5 \%$ to cefotaxime, $11.11 \%$ to amoxiclav. Among the gram-positives, $100 \%$ of the isolates were sensitive to meropenem, $95.8 \%$ to vancomycin, $91.6 \%$ to linezolid, $87.5 \%$ are sensitive to norfloxacin and amikacin, $83.3 \%$ to ofloxacin, $79.1 \%$ to piperacillin plus tazobactam, $70.8 \%$ to chloramphenicol and nitrofurantoin, $33.3 \%$ to cefoperazone, $20.8 \%$ to amoxiclav. Multiple drug resistance (Resistance two or more drugs) was observed in $74 \%$ of the isolates.

\section{CONCLUSION}

Significant bacteriuria $(100,000 \mathrm{CFU} / \mathrm{mL}$ of Urine) was observed in both infants and children. Periodic studies are recommended to confirm the findings of this study and also monitor any changes in the susceptibility patterns of uropathogens causing urinary tract infection in these groups.

\section{KEYWORDS}

UTI, Infants, Children, Drug Susceptibility.

HOW TO CITE THIS ARTICLE: Sampathirao J, Budumuru R, Pappala BC. Bacterial profile and drug susceptibility pattern of urinary tract infection in infants and children. J. Evolution Med. Dent. Sci. 2016;5(25):1332-1335, DOI: 10.14260/jemds/2016/313

\section{INTRODUCTION}

In a Urinary Tract Infection (UTI), bacteria usually enter the urinary tract through the urethra. They may then travel up the urinary tract and infect the bladder (Cystitis) and the kidneys (Pyelonephritis). Most UTIs in children clear up quickly with proper antibiotic treatment.[1]

Financial or Other, Competing Interest: None.

Submission 09-02-2016, Peer Review 09-03-2016,

Acceptance 14-03-2016, Published 26-03-2016.

Corresponding Author:

Dr. Jyothiprakashraju Sampathirao,

Plot No: 485 ,

P.N. Colony,

Srikakulam-532001,

Andhra Pradesh.

E-mail: drradhikaprakash20@gmail.com

DOI: $10.14260 /$ jemds $/ 2016 / 313$
Urinary Tract Infections (UTIs) in children may not cause obvious urinary symptoms. Symptoms of UTI in an infant or young child may include: Fever - This may be the only symptom in infants, irritability, lack of appetite, failure to gain weight or develop normally, foul-smelling urine, crying during urination, vomiting or diarrhoea.[1,2]

Most Urinary Tract Infections (UTIs) in children are caused by bacteria that enter the urethra and travel up the urinary tract. Bacteria that normally live in the large intestine and are present in stool (Faeces) are the most common cause of infection. Sometimes bacteria traveling through the blood or lymph system to the urinary tract are the cause of kidney or bladder infections.[1,3]

The ways that bacteria build up can occur include not properly wiping the bottom after a bowel movement, bacteria may get into the urethra and cause an UTI, constipation, not 
completely emptying the bladder. This can cause bacteria to build up in urine.[1]

Problems with the structure or function of the urinary tract commonly contribute to UTIs in infants and young children. Problems that limit the body's ability to eliminate urine completely include:

A structural problem of the bladder that allows urine to flow backward to the kidneys (vesicoureteral reflux), an obstruction, such as a kidney stone that blocks, slows or disrupts the normal flow of urine through the urinary tract (Obstructions in the Urinary Tract), other abnormalities of the urinary tract. $[4,5]$

The biggest concern over UTIs in children is that they can cause permanent kidney damage and scarring. Repeated scarring can lead to high blood pressure and reduced kidney function including kidney failure. Infants and young children seem to be at higher risk for this complication. The risk of irreversible kidney damage makes early medical evaluation and treatment of UTIs in infants and young children very important. Unfortunately, detecting UTIs in infants and young children can be difficult. Unlike symptoms in older children and adults, symptoms in the very young can be vague and inconsistent. Serious short-term complications of UTIs are unusual, but do occur. They include an abscess in the urinary tract, acute kidney failure and widespread infection (sepsis), which can be life-threatening.[6,7]

The main aim of the study is to determine the prevalence of UTI as well as the effect of gender and age on its prevalence. The etiologic agents and their susceptibility pattern will also be determined.

\section{MATERIALS AND METHODS}

Midstream urine was collected from 100 clinically diagnosed cases of urinary tract infection who are attending to paediatric OP of GEMS Medical College, Ragolu, Srikakulam with symptoms of burning in micturition, strain in micturition and excessive cry during micturition.

\section{Inclusion Criteria}

Infants below 1 year and children below 12 years with symptoms of UTI.

\section{Exclusion Criteria}

Older children and adults with symptoms of UTI. Urinary tract abnormalities, post urethral valve, unstable bladder, etc. were also excluded.

\section{Sample Collection}

All the midstream urine samples were inoculated on Nutrient Agar, Blood Agar and MacConkey's Agar and incubated aerobically at $37^{\circ} \mathrm{c}$ for 18 hours and then examined. All organisms including gram positive and gram negative bacteria were subjected to a battery of tests as follows: Gram staining for morphology, hanging drop for motility, capsular staining using Congo red, for production of enzymes-Oxidase, Catalase, Nitrate reduction, Urease, for substrate utilizationCitrate utilization test, Malonate utilization, for metabolism of proteins and amino acids- Indole production, tests for specific breakdown products-Methyl red test, Voges-Proskauer (Acetoin production), tests for utilisation of carbohydrates of sugar media containing Glucose, Lactose, Xylose, Sucrose, Maltose, Mannitol.
Antibiotic sensitivity testing by Kirby-Bauer's disc diffusion method for the following drugs:

\begin{tabular}{|c|c|}
\hline For Gram Positive Bacteria & For Gram Negative Bacteria \\
\hline Vancomycin $(10 \mu \mathrm{g})$ & - \\
\hline Ofloxacin $(10 \mu \mathrm{g})$ & - \\
\hline Norfloxacin $(30 \mu \mathrm{g})$ & Amikacin $(30 \mu \mathrm{g})$ \\
\hline Cotrimoxazole $(23.75 \mu \mathrm{g})$ & Cotrimoxazole $(23.75 \mu \mathrm{g})$ \\
\hline Nitrofurantoin & Nitrofurantoin \\
\hline Amikacin & Amikacin \\
\hline Chloramphenicol & Gentamicin \\
\hline Meropenem $(10 \mu \mathrm{g})$ & Meropenem $(10 \mu \mathrm{g})$ \\
\hline Piperacillin plus tazobactam & Ampicillin plus tazobactam \\
\hline Linezolid & \\
\hline Cefoperazone $(30 \mu \mathrm{g})$ & Cefotaxime $(30 \mu \mathrm{g})$ \\
\hline Amoxiclav & Amoxiclav \\
\hline
\end{tabular}

\section{RESULTS}

Out of 100 kids with symptoms of UTI, 19 (19\%) were infants (Below 1 yr.), 81 (81\%) were children (Below 12 yrs.); 56 (56\%) were boys and $44(44 \%)$ were girls. Culture of midstream urine specimens revealed that 66/100 (66\%) had significant bacteriuria in these groups (Table 1).

The gram positive and negative bacteria accounted $12 \%$ and 54\% respectively. The bacterial pathogens isolated were predominantly E. coil 31 (46.9\%) followed by K. pneumonia 17 (25.7\%), Proteus spp. 3 (4.54\%), coagulase-negative staphylococci, Pseudomonas aeruginosa 4 (6.06\%). Others found in small number included coagulase negative Staphylococci 7 (10.6\%), Enterococci $3(4.54 \%)$ and nonGroup A-beta haemolytic Streptococcus 1 (1.54\%) (Table 1).

The susceptibility pattern for gram-negative bacteria showed $100 \%$ sensitivity to meropenem, $96.2 \%$ to nitrofurantoin, $94.4 \%$ to amikacin, $87.01 \%$ to ampicillin plus tazobactam, $81.4 \%$ to gentamycin, $79 \%$ to ofloxacin, $72.2 \%$ to cotrimoxazole, $55.5 \%$ to cefotaxime, $11.11 \%$ to amoxiclav (Table 3).

Among the gram-positives $100 \%$ of the isolates were sensitive to meropenem, $91.6 \%$ are sensitive to norfloxacin and amikacin, $75 \%$ to vancomycin, $66.6 \%$ to piperacillin plus tazobactam, $50 \%$ to chloramphenicol, $41.66 \%$ to amoxiclav, $33.3 \%$ to cefoperazone, $25 \%$ to ofloxacin, $16.6 \%$ to nitrofurantoin (Table 2).

Multiple drug resistance (Resistance two or more drugs) was observed in $74 \%$ of the isolates.

\begin{tabular}{|c|c|c|c|}
\hline $\begin{array}{l}\text { Sl. } \\
\text { No. }\end{array}$ & Organisms & $\begin{array}{l}\text { No. of } \\
\text { Cases }\end{array}$ & $\begin{array}{l}\text { Percentage } \\
\text { (\%) }\end{array}$ \\
\hline 1 & Escherichia coli & 31 & $46.9 \%$ \\
\hline 2 & Klebsiella spp. & 17 & $25.7 \%$ \\
\hline 3 & Proteus spp. & 3 & $4.54 \%$ \\
\hline 4 & Pseudomonas spp. & 4 & $6.06 \%$ \\
\hline 5 & $\begin{array}{l}\text { Coagulase negative } \\
\text { Staphylococci spp. }\end{array}$ & 7 & $10.6 \%$ \\
\hline 6 & Enterococci & 3 & $4.54 \%$ \\
\hline \multirow[t]{2}{*}{7} & Streptococci spp. & 1 & $1.51 \%$ \\
\hline & Total & 66 & \\
\hline Tab & $\begin{array}{r}\text { tribution of Organ } \\
\text { Tract Infe }\end{array}$ & $\begin{array}{l}\text { in } 66 c \\
s\end{array}$ & of Urinary \\
\hline
\end{tabular}




\begin{tabular}{|c|c|c|c|c|c|c|c|c|c|c|c|c|c|c|c|c|c|c|}
\hline \multirow[t]{2}{*}{$\begin{array}{l}\dot{z} \\
\dot{n}\end{array}$} & \multirow[t]{2}{*}{ 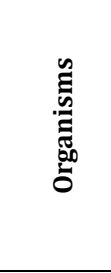 } & \multirow[t]{2}{*}{ 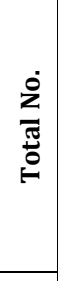 } & \multicolumn{2}{|c|}{ 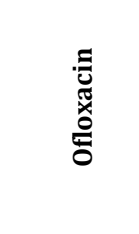 } & \multicolumn{2}{|c|}{ 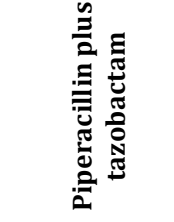 } & \multicolumn{2}{|c|}{ 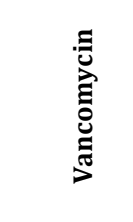 } & \multicolumn{2}{|c|}{ 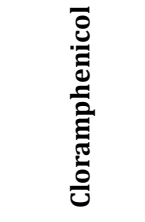 } & \multicolumn{2}{|c|}{ 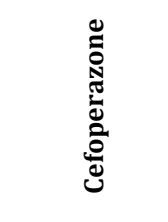 } & \multicolumn{2}{|c|}{ 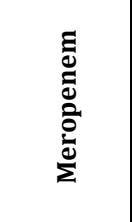 } & \multicolumn{2}{|c|}{ 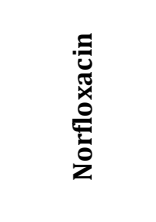 } & \multicolumn{2}{|c|}{ 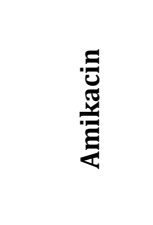 } \\
\hline & & & $\mathbf{S}$ & $\mathbf{R}$ & $S$ & $\mathbf{R}$ & $\mathbf{S}$ & $\mathbf{R}$ & $S$ & $\mathbf{R}$ & $S$ & $\mathbf{R}$ & $S$ & $\mathbf{R}$ & $\mathbf{S}$ & $\mathbf{R}$ & $\mathbf{S}$ & $\mathbf{R}$ \\
\hline 1 & $\begin{array}{c}\text { Gram } \\
\text { positive } \\
\text { bacteria }\end{array}$ & 23 & $\begin{array}{l}79 \\
\%\end{array}$ & $\begin{array}{l}75 \\
\%\end{array}$ & $\begin{array}{c}66.6 \\
\%\end{array}$ & $\begin{array}{c}33.4 \\
\%\end{array}$ & $\begin{array}{l}75 \\
\%\end{array}$ & $\begin{array}{l}25 \\
\%\end{array}$ & $\begin{array}{l}50 \\
\%\end{array}$ & $\begin{array}{l}50 \\
\%\end{array}$ & $\begin{array}{c}33.3 \\
\%\end{array}$ & $\begin{array}{c}66.7 \\
\%\end{array}$ & $\begin{array}{c}100 \\
\%\end{array}$ & $\begin{array}{l}0 \\
\%\end{array}$ & $\begin{array}{c}91.6 \\
\%\end{array}$ & $\begin{array}{c}8.4 \\
\%\end{array}$ & $\begin{array}{c}91.6 \\
\%\end{array}$ & $\begin{array}{c}8.4 \\
\%\end{array}$ \\
\hline & & & & & & Tabl & 2: $A$ & iog & of $G$ & $P o$ & ve Cou & & & & & & & \\
\hline
\end{tabular}

S - Sensitive, R - Resistance

\begin{tabular}{|c|c|c|c|c|c|c|c|c|c|c|c|c|c|c|c|c|c|c|}
\hline \multirow[t]{2}{*}{$\begin{array}{l}\dot{z} \\
\dot{\omega}\end{array}$} & \multirow[t]{2}{*}{ 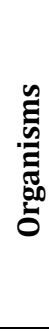 } & \multirow[t]{2}{*}{ 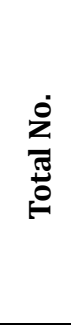 } & \multicolumn{2}{|c|}{ 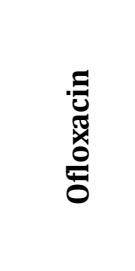 } & \multicolumn{2}{|c|}{ 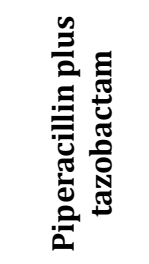 } & \multicolumn{2}{|c|}{ 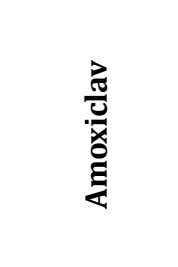 } & \multicolumn{2}{|c|}{ 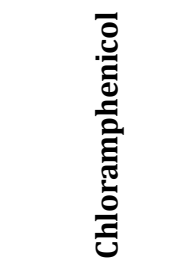 } & \multicolumn{2}{|c|}{ 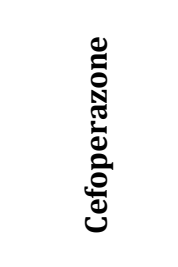 } & \multicolumn{2}{|c|}{ 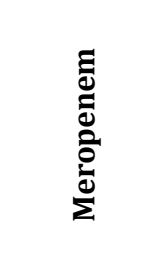 } & \multicolumn{2}{|c|}{ 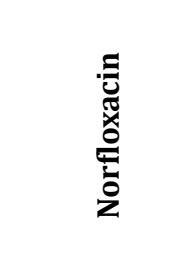 } & \multicolumn{2}{|c|}{ 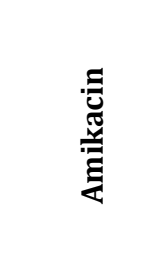 } \\
\hline & & & $\mathbf{S}$ & $\mathbf{R}$ & $\mathbf{S}$ & $\mathbf{R}$ & $\mathbf{S}$ & $\mathbf{R}$ & $\mathbf{S}$ & $\mathbf{R}$ & $\mathbf{S}$ & $\mathbf{R}$ & $\mathbf{S}$ & $\mathbf{R}$ & & $\mathbf{R}$ & $\mathbf{S}$ & $\mathbf{R}$ \\
\hline 1 & 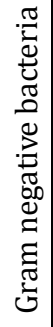 & 77 & $\begin{array}{l}79 \\
\%\end{array}$ & $\begin{array}{l}21 \\
\%\end{array}$ & $\begin{array}{c}87 . \\
\%\end{array}$ & $\begin{array}{l}13 \\
\%\end{array}$ & $\begin{array}{c}11.1 \\
\%\end{array}$ & $\begin{array}{c}88.9 \\
\%\end{array}$ & $\begin{array}{c}81.4 \\
\%\end{array}$ & $\begin{array}{c}18.6 \\
\%\end{array}$ & $\begin{array}{c}55.5 \\
\%\end{array}$ & $\begin{array}{c}44.5 \\
\%\end{array}$ & $\begin{array}{c}100 \\
\%\end{array}$ & $\begin{array}{l}0 \\
\%\end{array}$ & $\begin{array}{c}72.2 \\
\%\end{array}$ & $\begin{array}{c}27.8 \\
\%\end{array}$ & $\begin{array}{c}94.4 \\
\%\end{array}$ & $\begin{array}{c}5.6 \\
\%\end{array}$ \\
\hline
\end{tabular}

S - Sensitive, R - Resistance

\section{DISCUSSION}

This work demonstrated that significant bacteriuria $(100,000$ $\mathrm{CFU} / \mathrm{mL}$ of urine) was observed in both infants and children. Sixty six out of 100 patients developed UTI.

The percentage of infection in infants (19\%) in the present study is same as in the study of H. Solanki et al. (20\%).[8] and the percentage of infection in children (81\%) in the present study is same as in the study of H. Solanki et al.[8] (Turky) (80\%) and Abuhandan et al.[9] (India) (100\%).
However, the percentage of infection in infants is higher in studies of Seyed Reza Mirsoleymani et al.[10] (67.3\%) and Ramiro J Madden-Fuentes et al.[11] (86.04\%) and the percentage of infection in children is lower accounting for $32.7 \%$ and $13.95 \%$ respectively.

The ratio of male:female is similar in almost 3 studies. They are present study (3.5:2.75), H. Solanki.[8], P. Patra et al. (3:2) and Seyed Reza Mirsoleymani et al.[10] (3:2).

\begin{tabular}{|c|c|c|c|c|}
\hline $\begin{array}{c}\text { Organism } \\
\text { Isolated }\end{array}$ & $\begin{array}{c}\text { Present } \\
\text { Study }\end{array}$ & $\begin{array}{c}\text { H. Solanki, } \\
\text { P. Patra et al. }\end{array}$ & $\begin{array}{c}\text { M. Barton, } \\
\text { Y. Bell et al. }\end{array}$ & $\begin{array}{c}\text { Seyed Reza } \\
\text { Mirsoleymani et al. }\end{array}$ \\
\hline Escherichia coli & $46.9 \%$ & $43 \%$ & $31 \%$ & $65.2 \%$ \\
\hline Klebsiella spp. & $25.7 \%$ & $36 \%$ & $29 \%$ & $26 \%$ \\
\hline Proteus spp. & $4.54 \%$ & $22 \%$ & $6 \%$ & $-6 \%$ \\
\hline Pseudomonas spp. & $6.06 \%$ & - & $2 \%$ & Staphylococcus \\
aureus-3.7\% \\
\hline $\begin{array}{c}\text { Coagulase negative } \\
\text { Staphylococci spp. }\end{array}$ & $10.6 \%$ & $16 \%$ & $4 \%$ & - \\
\hline Enterococci & $4.54 \%$ & - & - & - \\
\hline Streptococci spp. & $1.54 \%$ & - & - \\
\hline
\end{tabular}

The percentage of isolation of E. coli and Klebsiella spp. are same in all studies.

The percentage of isolation of proteus is same in three studies except H. Solanki et al.[8] study.

Pseudomonas aeruginosa isolated only in two studies. They are present study and M. Barton Y Bell et al.[12] study.

The percentage of isolation of coagulase negative staphylococci of present study coincides with H. Solanki.[8] et al. study. Enterococci and Streptococci are isolated in present study only. 


\begin{tabular}{|c|c|c|c|}
\hline Antibiotics & $\begin{array}{c}\text { Present } \\
\text { Study }\end{array}$ & $\begin{array}{c}\text { Seyed Reza } \\
\text { Mirsoley } \\
\text { mani } \\
\text { et al. }\end{array}$ & $\begin{array}{l}\text { Abuhan } \\
\text { dam et al. }\end{array}$ \\
\hline Ceftriaxone & - & $41.8 \%$ & $39.5 \%$ \\
\hline Nitrofurantoin & $96.2 \%$ & - & $19.7 \%$ \\
\hline $\begin{array}{c}\text { Ampicillin - } \\
\text { sulbactam }\end{array}$ & $87.01 \%$ & - & $64.1 \%$ \\
\hline Cotrimoxazole & $72.2 \%$ & - & $41.5 \%$ \\
\hline Amoxiclav & $11.11 \%$ & - & $51.7 \%$ \\
\hline Cefuroxime & - & - & $38.1 \%$ \\
\hline Amikacin & $94.4 \%$ & $79.7 \%$ & - \\
\hline Ofloxacin & $79 \%$ & $78.3 \%$ & - \\
\hline Gentamycin & $81.4 \%$ & $71.6 \%$ & - \\
\hline Cefotaxime & $55.5 \%$ & $41.4 \%$ & - \\
\hline Meropenem & $100 \%$ & - & $100 \%$ \\
\hline
\end{tabular}

All the isolates are resistant to Cefotaxime, Amoxiclav. The most effective drugs are Meropenem, Amikacin and Gentamycin.

\section{CONCLUSION}

Significant bacteriuria $(100,000 \mathrm{CFU} / \mathrm{mL}$ of urine $)$ was observed in both infants and children. Periodic studies are recommended to confirm the findings of this study and also monitor any changes in the susceptibility patterns of uropathogens causing urinary tract infection in these groups.

\section{REFERENCES}

1. Kliegman RM, Stanton BF, St. Geme JW III, et al. Urinary tract infections. Nelson textbook of Pediatrics. Saunders Elsevier, Philadelphia: chap 169, 2011;19th ed.

2. Beetz R. May we go on with antibacterial prophylaxis for urinary tract infections? Pediatric Nephrology 2006;21:5-13.
3. Quigley R. Diagnosis of urinary tract infections in children. Current Opinion in Pediatrics 2009;21(2):194-198.

4. Vachvanichsanong P. Urinary tract infection: one lingering effect of childhood kidney diseases-review of the literature. Journal of Nephrology 2007;20(1):21-28.

5. Bhat RG, Katy TA, Place FC. Pediatric urinary tract infections. Emergency Medicine Clinics of North America 2011;29(3):637-653.

6. López Sastre JB, Aparicio AR, Coto Cotallo GD, et al. Urinary tract infection in the newborn: clinical and radio imaging studies. Pediatric Nephrology 2011;22(10):1735-1741.

7. Yang SS, Chiang IN, Lin CD, et al. Advances in nonsurgical treatments for UTIs in children. World Journal of Urology 2012;30(1):69-75.

8. Solanki H, Patva P. Utility of dipstick versus urine culture in diagnosis of urinary tract infection in children. Gujarath Medical Journal 2010;65(1):20-22.

9. Abuhandan M, Güzel B, Oymak Y, et al. Antibiotic sensitivity and resistance in children with urinary tract infection in Sanliurfa. Turk J Urol 2013;39(2):106-110.

10. Seyedreza mirsoleymani, Morteza Salimi, Masoud Shareghi Brojeni, et al. Bacterial pathogens and antimicrobial resistance patterns in pediatric urinary tract infections: a four-year surveillance study (20092012). International Journal of Pediatrics Article ID 126142, 2014;Vol 2014:p 6. http://dx.doi.org/10.1155/2014/126142

11. Madden-Fuentes RJ, McNamara ER, Nseyo U, et al. Resolution rate of isolated low-grade hydronephrosis diagnosed within the first year of life. J Pediatr Urol 2014;10(4):639-644.

12. Barton $M$, Bell $Y$, Thame $M$, et al. Urinary tract infection in neonates with serious bacterial infections admitted to the university hospital of the West Indies. West India Med J 2008;57(2):101-5. 